\title{
School characteristics and adolescent smoking. Results from the MRC/Derbyshire Smoking Study 1974-8 and from a follow up in 1981
}

\author{
M MURRAY, S KIRYLUK, AND A V SWAN \\ From the Department of Community Medicine, United Medical and Dental Schools of Guy's and St Thomas's \\ Hospitals, St Thomas' Hospital Medical School, London SE1 7EH, UK
}

SUMMARY In the MRC/Derbyshire Smoking Study a cohort of about 6000 adolescents was surveyed annually from 1974 when they entered secondary school aged 11-12 years until 1978 when they reached 15-16 years. In 1981 after the adolescents had left school they were again surveyed by post. Each year from 1974 to 1978 and again in 1981 they answered a questionnaire on their smoking behaviour and other issues. Information on the schools attended by these adolescents was obtained from their teachers and headteachers. This paper examines the relation between the school environment and the adolescents' smoking behaviour both before and after leaving school. The prevalence of smoking was higher among those boys who attended schools that were single sex, non-denominational, or had a parent-teacher asociation, no health education, no female teachers, or whose headteacher smoked cigarettes. Among girls the prevalence of smoking was higher if they attended a school that had optional school uniform and no health or antismoking education. The importance of these findings for the development of effective preventive measures is discussed.

Several studies have suggested that certain school characteristics may raise the risk of the pupils adopting smoking. Findings, however, have not been consistent. A study in Hounslow concluded that smoking was more common among girls who attended mixed comprehensive schools than among those who attended a single sex comprehensive or a single sex grammar school. ${ }^{1}$ Little relation was found between the prevalence of smoking among boys and the type of school they attended. The National Child Development Study, however, found that smoking was more prevalent among all pupils in comprehensive or secondary modern schools than among pupils in grammar schools. ${ }^{2}$

Other studies concentrated on the schools' disciplinary practices. Palmer, in 1965 , found that the caning of boys caught smoking was associated with heavier smoking. ${ }^{3}$ More recently, Porter contrasted the smoking practices of the "old boys" of two public schools with different disciplinary practices." Smokers were more likely to come from the school that permitted pupils to smoke.

These few studies were either cross sectional in design or based on rather small samples. The
MRC/Derbyshire Smoking Study, ${ }^{5}$ which is a large longitudinal study, provided an opportunity for a thorough analysis of the relation between school organisation and adolescent smoking. Earlier reports from this study considered the relation of school type and teachers' smoking behaviour to the smoking practices of 11-12 year olds. ${ }^{5}$ This paper considers the relation between a variety of school characteristics and the smoking practices of teenagers aged between 15 and 16 while at school and of the same teenagers after they had left school and had reached age 18-19.

\section{Method}

In the MRC/Derbyshire Smoking Study a cohort of about 6000 adolescents was followed up from 1974 when they were aged 1i-12 until 1978 when they reached 15-16. In 1981 a follow up survey of the original cohort was conducted. Each year while they were at school (1974-8) the adolescents answered a questionnaire in their classrooms under the supervision of their teacher. The questionnaire requested details of the adolescents' smoking practices, social activities, and attitudes towards 
various issues. In 1974 and 1978 a similar questionnaire was sent to their parents. In 1981 a short questionnaire requesting details of their smoking behaviour was sent to each adolescent in the original cohort whose address was available from the 1978 school class lists.

In 1974 and 1975 their school teachers answered a short questionnaire about their own smoking practices, while in 1974 and 1978 the headteachers answered a questionnaire about school organisation and their own smoking practices. Replies by teachers and headteachers in 1974 and 1978 were linked to form a number of school organisation variables. Some of these school variables were derived from information obtained only in 1974 (catchment area, uniform, sixth form, denomination, headteacher smoking, teachers smoking) or only in 1978 (pastoral care system). The rest were obtained from information collected in both years (school size, parent-teachers' association, sex of pupils, health and antismoking education, corporal punishment for smokers). Some attempt was made to assess the effect of class formation-for instance, streaming, etc. Unfortunately, as information on this was sparse and ambiguous it was omitted from the analysis.

Forty eight schools entered the survey in 1974. During the next five years nine of these schools either closed or amalgamated owing to reorganisation and four others were either middle schools or junior comprehensives. The analysis reported is restricted to the remaining 35 schools which the adolescents could attend for the full five years. The 1974 prevalence of adolescent smoking-that is, proportion smoking at least one cigarette a week-in these 35 schools was similar to that in the 13 schools excluded from the analysis $(4 \cdot 2 \% v 4 \cdot 3 \%)$.

Of the 5133 11-12 year olds in the 35 schools who were surveyed in $1974,3513(68 \cdot 4 \%)$ were traced in 1978 and 2723 (53\%) in 1981. Those children who were lost from the survey after 1974 were more likely to have smoked. In addition, the 1981 response rates of those not smoking in 1978 was $80 \%$ while for the smokers it was $69 \%$. Since more smokers were lost to follow up the 1981 smoking prevalences are likely to be underestimated by about one tenth. The response rates also differed according to school characteristics. For example, it was $27 \%$ lower in children from schools without health education (81\% v 54\%). Nevertheless, the analyses are comparative in nature, looking at the smoking practices of groups of adolescents with and without particular characteristics. Since the proportion of smokers in the non-respondents did not differ systematically between the various groups compared, the estimated effects of the school characteristics are very little affected by non-response bias.
The analysis was performed by fitting a series of regression models ${ }^{7}$ which allowed us to estimate the extent of the relation between each school organisation variable and the prevalence of smoking among the adolescents before and after leaving school. These analyses took account of the child variables already known $^{8}$ to be associated with smoking which included the smoking behaviour of the adolescents' parents and siblings, their own smoking behaviour at 11-12 years, and their friendship patterns. In addition, since the patterns of association were found to differ according to the adolescents' sex, separate regression analyses were conducted for boys and girls.

\section{Results}

In 1978 the prevalence of boys smoking in the 35 schools ranged from $7 \%$ to $38 \%$ whereas among girls of the same age it ranged from $8 \%$ to $33 \%$. Three years later after the adolescents had left school the prevalence in the groups classified by school attended ranged from $13 \%$ to $48 \%$ for the boys and $7 \%$ to $39 \%$ among the girls.

An initial regression analysis ignoring the differences in school organisation found the $\vec{D}$ differences among the 35 schools in the prevalence of adolescent smoking in both 1978 and 1981 to be highly significant. These differences remained when $\vec{c}$ comparisons were made within the 1974 smokingo categories-that is, the smoking behaviour witho which the adolescents entered those schools. Theo. $\vec{\theta}$ purpose of the subsequent analyses was thus to? determine whether the variation among schools could be explained by differences in school organisation.

Tables 1-3 give the 1978 and 1981 prevalence of adolescent smoking within each category of the school organisation variables. Some school characteristics appeared from the marginal totals to be related to adolescent smoking but several of the relationships failed to reach significance in the regression analyses. Only those relationships that reached the $5 \%$ level of significance are reported.

Among 15-16 year old boys six school characteristics were significantly associated with increased smoking. The prevalence of smoking was higher in schools that were all boys, non-denominational, or had a parent teacher association, no health education, no female teachers, or a headteacher who smoked cigarettes. After the children left school three of these relationships remained significant. The prevalence of smoking was higher in schools that had a parent teacher association, no health education, or a headteacher who smoked. In addition, among the 18-19 year old boys two other school factors appeared to be 
Table 1 Prevalence of smoking among adolescents in 1978 and 1981 in relation to their school character

\begin{tabular}{|c|c|c|c|c|c|c|c|c|}
\hline \multirow{2}{*}{ Catchment area (1974): } & \multicolumn{4}{|c|}{$\begin{array}{l}\text { Male } \\
\text { \% Smokers (No) }\end{array}$} & \multicolumn{4}{|c|}{$\begin{array}{l}\text { Female } \\
\text { \% Smokers (No) }\end{array}$} \\
\hline & \multicolumn{2}{|c|}{$15-16 y$} & \multicolumn{2}{|c|}{$18-19 y$} & \multicolumn{2}{|c|}{$15-16 y$} & \multicolumn{2}{|c|}{$18-19 y$} \\
\hline $\begin{array}{l}\text { Rural } \\
\text { Surburban/mixed } \\
\text { Urban }\end{array}$ & $\begin{array}{l}24 \\
21 \\
25\end{array}$ & $\begin{array}{l}(186) \\
(776) \\
(755)\end{array}$ & $\begin{array}{l}31 \\
28 \\
29\end{array}$ & $\begin{array}{l}(153) \\
(633) \\
(515)\end{array}$ & $\begin{array}{l}25 \\
22 \\
21\end{array}$ & $\begin{array}{l}(218) \\
(763) \\
(815)\end{array}$ & $\begin{array}{l}31 \\
26 \\
23\end{array}$ & $\begin{array}{l}(176) \\
(638) \\
(176)\end{array}$ \\
\hline $\begin{array}{l}\text { School type }(1974-8) \text { : } \\
\text { Grammar } \\
\text { Grammar/comprehensive } \\
\text { Comprehensive } \\
\text { Secondary mod/comprehensive } \\
\text { Secondary modern }\end{array}$ & $\begin{array}{l}29 \\
22 \\
22 \\
26 \\
38\end{array}$ & $\begin{array}{r}(45) \\
(165) \\
(1320) \\
(158) \\
(29)\end{array}$ & $\begin{array}{l}46 \\
23 \\
27 \\
36 \\
46\end{array}$ & $\begin{array}{l}(41) \\
(146) \\
(962) \\
(126) \\
(26)\end{array}$ & $\begin{array}{l}33 \\
16 \\
21 \\
29 \\
10\end{array}$ & $\begin{array}{r}(46) \\
(155) \\
(1384) \\
(182) \\
(29\end{array}$ & $\begin{array}{r}25 \\
22 \\
25 \\
31 \\
8\end{array}$ & $\begin{array}{r}(40) \\
(142) \\
(1068) \\
(148) \\
(24)\end{array}$ \\
\hline $\begin{array}{l}\text { Sex of school pupils }(1974-8) \text { : } \\
\text { Single sex } \\
\text { Single sex/mixed } \\
\text { Mixed }\end{array}$ & $\begin{array}{l}32 \\
29 \\
22\end{array}$ & $\begin{array}{r}(78) \\
(79) \\
(1560)\end{array}$ & $\begin{array}{l}28 \\
34 \\
28\end{array}$ & $\begin{array}{r}(69) \\
(67) \\
(1165)\end{array}$ & $\begin{array}{l}18 \\
22 \\
22\end{array}$ & $\begin{array}{r}(79) \\
(76) \\
(1641)\end{array}$ & $\begin{array}{l}18 \\
25 \\
26\end{array}$ & $\begin{array}{r}(71) \\
(65) \\
(1286)\end{array}$ \\
\hline $\begin{array}{l}\text { Size of school }(1974-8) \text { : } \\
\text { Small }(<600) \\
\text { Growing } \\
\text { Medium }(601-1000) \\
\text { Large }(>1000)\end{array}$ & $\begin{array}{l}23 \\
25 \\
23 \\
22\end{array}$ & $\begin{array}{l}(151) \\
(354) \\
(603) \\
(609)\end{array}$ & $\begin{array}{l}35 \\
28 \\
29 \\
26\end{array}$ & $\begin{array}{l}(124) \\
(293) \\
(482) \\
(402)\end{array}$ & $\begin{array}{l}25 \\
20 \\
22 \\
22\end{array}$ & $\begin{array}{l}(155) \\
(447) \\
(571) \\
(623)\end{array}$ & $\begin{array}{l}32 \\
24 \\
26 \\
24\end{array}$ & $\begin{array}{l}(125) \\
(364) \\
(474) \\
(459)\end{array}$ \\
\hline $\begin{array}{l}\text { Denomination (1974): } \\
\text { Denominational } \\
\text { Non-denominational }\end{array}$ & $\begin{array}{l}19 \\
24\end{array}$ & $\begin{array}{r}(185) \\
(1532)\end{array}$ & $\begin{array}{l}28 \\
29\end{array}$ & $\begin{array}{l}(142) \\
(1159)\end{array}$ & $\begin{array}{l}18 \\
22\end{array}$ & $\begin{array}{r}(250) \\
(1546)\end{array}$ & $\begin{array}{l}25 \\
25\end{array}$ & $\begin{array}{r}(203) \\
(1219)\end{array}$ \\
\hline $\begin{array}{l}\text { Uniform (1974): } \\
\text { Compulsory } \\
\text { Non-compulsory }\end{array}$ & $\begin{array}{l}23 \\
25\end{array}$ & $\begin{array}{r}(1363) \\
(354)\end{array}$ & $\begin{array}{l}28 \\
33\end{array}$ & $\begin{array}{r}(1095) \\
(206)\end{array}$ & $\begin{array}{l}20 \\
27\end{array}$ & $\begin{array}{r}(1365) \\
(431)\end{array}$ & $\begin{array}{l}24 \\
29\end{array}$ & $\begin{array}{r}(1121) \\
(301)\end{array}$ \\
\hline $\begin{array}{l}\text { Parent teachers association }(1974-8 \\
\text { Has PTA } \\
\text { Gains PTA } \\
\text { No PTA }\end{array}$ & $\begin{array}{l}24 \\
23 \\
20\end{array}$ & $\begin{array}{r}(1126) \\
(281) \\
(310)\end{array}$ & $\begin{array}{l}30 \\
30 \\
22\end{array}$ & $\begin{array}{l}(888) \\
(234) \\
(179)\end{array}$ & $\begin{array}{l}21 \\
23 \\
22\end{array}$ & $\begin{array}{r}(1113) \\
(284) \\
(399)\end{array}$ & $\begin{array}{l}24 \\
32 \\
25\end{array}$ & $\begin{array}{l}(908) \\
(232) \\
(282)\end{array}$ \\
\hline $\begin{array}{l}\text { Sixth Form (1974): } \\
\text { Has one } \\
\text { Does not have one }\end{array}$ & $\begin{array}{l}23 \\
24\end{array}$ & $\begin{array}{r}(1159) \\
(558)\end{array}$ & $\begin{array}{l}28 \\
30\end{array}$ & $\begin{array}{l}(864) \\
(437)\end{array}$ & $\begin{array}{l}21 \\
22\end{array}$ & $\begin{array}{r}(1147) \\
(649)\end{array}$ & $\begin{array}{l}26 \\
25\end{array}$ & $\begin{array}{l}(910) \\
(512)\end{array}$ \\
\hline $\begin{array}{l}\text { Pastoral care (1978): } \\
\text { Vertical } \\
\text { Year grouping }\end{array}$ & $\begin{array}{l}24 \\
23\end{array}$ & $\begin{array}{r}(302) \\
(1348)\end{array}$ & $\begin{array}{l}27 \\
29\end{array}$ & $\begin{array}{l}(244) \\
(1000)\end{array}$ & $\begin{array}{l}24 \\
21\end{array}$ & $\begin{array}{r}(306) \\
(1426)\end{array}$ & $\begin{array}{l}29 \\
24\end{array}$ & $\begin{array}{r}(252) \\
(1119)\end{array}$ \\
\hline
\end{tabular}

Table 2 Prevalence of smoking among adolescents in 1978 and 1981 in relation to their schools' policies on smoking

\begin{tabular}{|c|c|c|c|c|c|c|c|c|}
\hline \multirow{2}{*}{ Health education (1974 } & \multicolumn{4}{|c|}{$\begin{array}{l}\text { Male } \\
\text { \% Smokers (No) }\end{array}$} & \multicolumn{4}{|c|}{$\begin{array}{l}\text { Female } \\
\text { \% Smokers (No) }\end{array}$} \\
\hline & \multicolumn{2}{|c|}{$15-16 y$} & \multicolumn{2}{|c|}{$18-19 y$} & \multicolumn{2}{|c|}{$15-16 y$} & \multicolumn{2}{|c|}{$18-19 y$} \\
\hline $\begin{array}{l}\text { Health education (197 } \\
\text { None/little } \\
\text { Throughout }\end{array}$ & $\begin{array}{l}27 \\
22\end{array}$ & $\begin{array}{r}(226) \\
(1491)\end{array}$ & $\begin{array}{l}37 \\
28\end{array}$ & $\begin{array}{l}(110) \\
(1191)\end{array}$ & $\begin{array}{l}26 \\
21\end{array}$ & $\begin{array}{r}(238) \\
(1558)\end{array}$ & $\begin{array}{l}31 \\
25\end{array}$ & $\begin{array}{r}(143) \\
(1279)\end{array}$ \\
\hline $\begin{array}{l}\text { Antismoking education } \\
\text { None } \\
\text { Only in later years } \\
\text { Only in early years } \\
\text { Throughout }\end{array}$ & $\begin{array}{l}22 \\
24 \\
21 \\
24\end{array}$ & $\begin{array}{l}(554) \\
(752) \\
(119) \\
(292)\end{array}$ & $\begin{array}{l}31 \\
30 \\
20 \\
23\end{array}$ & $\begin{array}{l}(437) \\
(540) \\
(80) \\
(244)\end{array}$ & $\begin{array}{l}25 \\
21 \\
13 \\
17\end{array}$ & $\begin{array}{l}(780) \\
(737) \\
(111) \\
(168)\end{array}$ & $\begin{array}{l}27 \\
26 \\
14 \\
19\end{array}$ & $\begin{array}{l}(639) \\
(551) \\
(92) \\
(140)\end{array}$ \\
\hline $\begin{array}{l}\text { Corporal punishment } \\
\text { None } \\
\text { Only in later years } \\
\text { Only in early years } \\
\text { Throughout }\end{array}$ & $\begin{array}{l}25 \\
19 \\
27 \\
22\end{array}$ & $\begin{array}{l}(373) \\
(298) \\
(183) \\
(863)\end{array}$ & $\begin{array}{l}31 \\
23 \\
37 \\
27\end{array}$ & $\begin{array}{l}(292) \\
(233) \\
(145) \\
(631)\end{array}$ & $\begin{array}{l}22 \\
22\end{array}$ & $\begin{array}{r}(1520) \\
(231)\end{array}$ & $\begin{array}{l}25 \\
25\end{array}$ & $\begin{array}{r}(1250) \\
(136)\end{array}$ \\
\hline
\end{tabular}


Table 3 Prevalence of smoking among adolescents in 1978 and 1981 in relation to their teachers' smoking practices

\begin{tabular}{|c|c|c|c|c|c|c|c|c|}
\hline & \multicolumn{4}{|c|}{$\begin{array}{l}\text { Male } \\
\% \text { Smokers (No) }\end{array}$} & \multicolumn{4}{|c|}{$\begin{array}{l}\text { Female } \\
\% \text { Smokers (No) }\end{array}$} \\
\hline & \multicolumn{2}{|c|}{$15-16 y$} & \multicolumn{2}{|c|}{$18-19 y$} & \multicolumn{2}{|c|}{$15-16 y$} & \multicolumn{2}{|c|}{$18-19 y$} \\
\hline $\begin{array}{l}<20 \% \\
\geqslant 20 \%\end{array}$ & $\begin{array}{l}22 \\
25\end{array}$ & $\begin{array}{r}(1013) \\
(704)\end{array}$ & $\begin{array}{l}28 \\
29\end{array}$ & $\begin{array}{l}(825) \\
(476)\end{array}$ & $\begin{array}{l}22 \\
21\end{array}$ & $\begin{array}{r}(1067) \\
(729)\end{array}$ & $\begin{array}{l}26 \\
25\end{array}$ & $\begin{array}{l}(881) \\
(541)\end{array}$ \\
\hline $\begin{array}{l}\text { Female teachers smoki } \\
\quad<20 \% \\
\geqslant 20 \%\end{array}$ & $\begin{array}{l}21 \\
24\end{array}$ & $\begin{array}{l}(858) \\
(781)\end{array}$ & $\begin{array}{l}27 \\
30\end{array}$ & $\begin{array}{l}(592) \\
(640)\end{array}$ & $\begin{array}{l}20 \\
24\end{array}$ & $\begin{array}{l}(992) \\
(804)\end{array}$ & $\begin{array}{l}21 \\
30\end{array}$ & $\begin{array}{l}(756) \\
(666)\end{array}$ \\
\hline $\begin{array}{l}\text { Teachers smoking (197 } \\
\quad<20 \% \\
\geqslant 20 \%\end{array}$ & $\begin{array}{l}21 \\
25\end{array}$ & $\begin{array}{l}(855) \\
(862)\end{array}$ & $\begin{array}{l}27 \\
30\end{array}$ & $\begin{array}{l}(677) \\
(624)\end{array}$ & $\begin{array}{l}19 \\
25\end{array}$ & $\begin{array}{l}(940) \\
(856)\end{array}$ & $\begin{array}{l}22 \\
29\end{array}$ & $\begin{array}{l}(777) \\
(645)\end{array}$ \\
\hline $\begin{array}{l}\text { Headteachers smoking } \\
\text { Non-smokers } \\
\text { Ex-smokers } \\
\text { Pipes/cigar smokers } \\
\text { Cigarette smokers }\end{array}$ & $\begin{array}{l}23 \\
23 \\
22 \\
28\end{array}$ & $\begin{array}{l}(663) \\
(399) \\
(471) \\
(184)\end{array}$ & $\begin{array}{l}28 \\
26 \\
28 \\
37\end{array}$ & $\begin{array}{l}(447) \\
(318) \\
(383) \\
(153)\end{array}$ & $\begin{array}{l}25 \\
19 \\
19 \\
22\end{array}$ & $\begin{array}{l}(733) \\
(456) \\
(426) \\
(181)\end{array}$ & $\begin{array}{l}25 \\
24 \\
25 \\
30\end{array}$ & $\begin{array}{l}(549) \\
(382) \\
(340) \\
(151)\end{array}$ \\
\hline
\end{tabular}

associated with an increase in smoking-attendance at a grammar school or no antismoking education.

Among 15-16 year old girls, four school factors were significantly associated with an increase in smoking. The prevalence of smoking was higher in schools that had optional school uniform, no health education, or no antismoking education in later years. The prevalence of smoking among girls whose headteacher was an ex-smoker or a pipe or cigar smoker was significantly lower than among those whose headteachers did not smoke. Girls with cigarette smoking headteachers had prevalences in between these but not significantly different from either. After leaving school only one of these factors, the absence of health education, was still significantly related to adolescent smoking. In addition, among the 18-19 year old girls the prevalence of smoking was significantly higher for those who had had many smoking female teachers.

\section{Discussion}

This study has shown that after allowing for the smoking practices of their families the prevalence of smoking among adolescents still differed greatly from school to school. Some of these differences were related to certain school characteristics. It is necessary, however, to be cautious in generalising from the relations suggested in this study. For example, the variation in the prevalence of older boys' smoking between schools classed as grammar and those classed as secondary modern is difficult to interpret since during the course of the study all the schools were undergoing varying degrees of reorganisation and the categories are imprecise. Nevertheless, several other school characteristics found to be associated with adolescent smoking can be interpreted and are relevant to today's schools.

The relative importance of some school characteristics apparently associated with smoking behaviour varied according to the sex of the children. Explanations as to why these school factors appear related to the development of smoking during adolescence must take these sex differences into account. Consideration must be given to why male and female patterns of behaviour during adolescence may differ.

Adolescence is an important period for the development of male and female identity. As Dovain noted, "around puberty the youngster experiences pressure and imperious expectations from parents and other adults, but most critically from members of the peer group, to perform the role of acceptable male or acceptable female."' It may be that certain school characteristics accentuate particular aspects of the male and female identity and so increase or reduce the risk of adolescents smoking.

The traditional male role includes such characteristics as competitiveness and independence which, if exaggerated, lead to rule breaking and risk taking. On the other hand, the traditional female role emphasises conformity and caution. During adolescence social norms and expectations detail the dimensions of these characteristics and to what extent each can be developed. Teacher expectations play their part in this process of the development of sex roles. For example, one study noted how to some teachers: "Bouncy girls are seen as a nuisance, rough, they're put down for it. Boys get more attention they're seen as a real lad, a good laugh. But teachers don't like girls who behave like that."'io

In those all boys schools with no female staff social 
norms may accentuate aspects of the male role. This, in turn, may increase the risk of smoking among boys explaining the significantly higher prevalences we found. A study of 12 year olds found that a majority of both boys and girls described the smoker as a "troublemaker" and as "liking to do forbidden things"- the very attributes of the exaggerated male role. ${ }^{11}$ The finding that boys appeared to smoke more in those schools with a parent-teacher association could support this model if the parent-teacher associations were established by the staff in an attempt to increase order when the pupils were troublesome.

At the other extreme are the schools where uniform was compulsory and antismoking education was provided. These are the characteristics we found to be significantly associated with lower prevalences, at least among the girls. It seems likely that these are the schools most likely to be encouraging the girls to acquire the traditional female characteristics of conformity and caution.

There was also a sex difference in the relation between teachers and adolescents smoking. All adult figures, including teachers, serve as models to adolescents in their social development. A previous analysis of the MRC/Derbyshire Study ${ }^{6}$ found that 11-12 year old boys were more likely to smoke if their male teachers smoked. There was no such relation, however, between the smoking practices of male teachers and those of the boys at $15-16$ or 18-19 but there was with headteachers smoking. This could indicate that the older boys react more to the general prosmoking ethos of a school where the head smokes rather than model themselves on the behaviour of individual teachers.

The investigation of the girls at 11-12 years ${ }^{6}$ did not show any effect of the smoking practices of female teachers. In the current analysis such an effect was apparent among them at 18-19 years. This is perhaps an indication that unlike the boys the girls do model their behaviour on their teachers during later adolescence. We also found that the 15-16 year old girls were less likely to smoke if their headteacher was a pipe or cigar smoker. This appears in slight contrast to the modelling effect but these headteachers were mostly men and were unlikely to serve as anything other than negative models to the girls. It is also possible that these headteachers operated a more vigorous antismoking policy in their schools than non-smokers.

The relative importance of health and antismoking education in predicting the smoking practices of adolescents even after they had left school was surprising. Previous reviews ${ }^{12}$ have suggested that most antismoking programmes are ineffective. In fact the health and antismoking education which took place in the schools in this study was generally uncoordinated and rather diffuse in content. It would be useful to conduct more detailed investigation of their actual content such that future health education programmes could be developed on a more scientific footing.

In conclusion, it would seem that the influence of various school organisation factors on the development of smoking during adolescence can be understood as part of a wider social psychological process. During adolescence the developing individual gradually acquires particular standards of adult behaviour. Schools may through their organisation unconsciously enforce certain behavioural standards, including sex role standards, more strenuously than others and in doing so increase the risk of their pupils smoking. In addition, the pupils model their behaviour on that of the teachers. This modelling effect varies in intensity during adolescence and is sex related.

This conclusion suggests that certain changes in school organisation could reduce the risk of adolescents smoking. Firstly, the mixing of boys and girls and of male and female staff might reduce the social norm for an exaggerated male role and the attendant greater risk of smoking by boys. Secondly, it might be possible to reduce the influence of the adult smoker by ensuring that such models are not apparent in the school through restrictions on smoking by teachers and other staff. Finally, specific antismoking programmes in schools should be based on an understanding of the different value of smoking to boys and girls and of how this can change during adolescence. Nevertheless, the effectiveness of such attempts by the school to combat the influence of those behavioural standards that are dominant in adult society will be limited unless supported by similar measures outside the school.

We thank the pupils and teachers in the schools who participated in this study and the Derbyshire Area Health and County Education Authorities for their cooperation. We also acknowledge the continuing support of Professor W W Holland.

Financial support for this study was provided by the Medical Research Council, the Department of Health and Social Security, and the Health Education Council.

\section{References}

\footnotetext{
${ }^{1}$ Rawbone RG, Keeling RA, Jenkins A. Cigarette smoking among secondary schoolchildren in 1975: its prevalence and some of the factors that promote smoking. Health Educ J 1979; 38: 92-9.
} 
${ }^{2}$ Pearson R, Richardson K. The smoking habits of 16 year olds in the National Child Development Study. Public Health 1978; 92: 136-44.

${ }^{3}$ Palmer JW. Smoking, caning, and delinquency in a secondary modern school. Br J Prev Soc Med 1965; 19: 18-23.

4Porter AMW. Disciplinary attitudes and cigarette smoking: a comparison of two schools. Br Med J 1982; 285: 1725-6.

${ }^{5}$ Banks MH, Bewley BR, Bland JM, Dean JR, Pollard V. Long-term study of smoking by secondary schoolchildren. Arch Dis Child 1978; 53: 12-9.

${ }^{6}$ Bewley BR, Johnson MRD, Banks MH. Teacher's smoking. J Epidemiol Community Health 1979; 33: 219-22.
${ }^{7}$ Baker RJ, Nelder JA. The Glim manual for system 3. Oxford: Numerical Algorithms Group, 1978.

${ }^{8}$ Murray M, Swan AV, Johnson MRD, Bewley BR. Some factors associated with increased risk of smoking by children. J Child Psychol Psychiat 1983; 24: 223-32.

${ }^{9}$ Douvain E. Sex role learning. In: Coleman JC, ed. The school years. London; Methuen, 1979.

${ }^{10}$ Griffin E, Hobson D, MacIntosh S, McCabe T. Women and leisure. In: Hargreaves J, ed. Sport, culture and ideology. London: Routledge and Kegan Paul, 1982.

${ }^{11}$ Bewley BR, Bland JM. The child's image of a young smoker. Health Educ J 1978; 37: 236-41.

${ }^{12}$ Thompson EL. Smoking education programmes, 1960-1976. Am J Public Health 1978; 68: 250-7.

\section{Correction}

Infantile hypertrophic pyloric stenosis in Greater Manchester (June 1983)

In table 1 the number of girls discharged in 1980 should read 15. 